\title{
When Law Migrates: Refugees in Comparative International Law
}

\section{Citation}

Goldenziel, Jill I. 2014. "When Law Migrates: Refugees in Comparative International Law." Public Law Research Paper 14-69, Boston University School of Law.

\section{Permanent link}

http://nrs.harvard.edu/urn-3:HUL.InstRepos:27314367

\section{Terms of Use}

This article was downloaded from Harvard University's DASH repository, and is made available under the terms and conditions applicable to Other Posted Material, as set forth at http:// nrs.harvard.edu/urn-3:HUL.InstRepos:dash.current.terms-of-use\#LAA

\section{Share Your Story}

The Harvard community has made this article openly available.

Please share how this access benefits you. Submit a story.

\section{Accessibility}




\title{
WHEN LAW MIGRATES: REFUGEES IN COMPARATIVE INTERNATIONAL LAW
}

\author{
Jill I. Goldenziel ${ }^{*}$
}

As record numbers of migrants have fled their countries in recent years, wealthier states have had an increasing interest in restricting their borders to protect national security. The challenge of balancing domestic security interests with international human rights commitments has fallen to courts. Drawing on cases from the U.S., Australia, and the European Court of Human Rights, this chapter will compare how the 1951 Convention Relating to the Status of Refugees has been interpreted across countries and over time. It will show how courts have permitted countries to circumvent the core prohibition of the Refugee Convention, and discuss when courts choose to intervene to enforce it. The chapter will conclude by analyzing the implications of these cases for extraterritorial application of domestic and international human rights guarantees.

\section{INTRODUCTION:}

Hugo Grotius famously said that the sea lies beyond the reach of sovereignty. ${ }^{1}$ Yet sovereignty over vessels on the high seas has long been contested. The practice of interdiction at sea has been particularly controversial in recent years. In this law enforcement activity, states' military or police vehicles halt irregular migrants before they reach land and return them to their country of departure. ${ }^{2}$ Faced with increasing migration, wealthy states have employed interdiction at sea to avoid their own stringent immigration rules and processes. States may also use this practice to circumvent their international legal obligations to asylum-seekers and refugees. ${ }^{3}$

\footnotetext{
* Research Fellow, Harvard Kennedy School, International Security Program, Belfer Center for Science and International Affairs. Ph.D., Government, Harvard University; A.M., Government, Harvard University; J.D., New York University School of Law; A.B., Princeton University. Thanks to Noah Feldman, Anthea Roberts, Kevin Rudd, Michael Pine, Mila Versteeg, and participants in the 2014 Sokol Colloquium in International Law at the University of Virginia.

${ }^{1}$ See Hugo Grotius, The Free Sea (David Armitage, ed., Richard Hakluyt, trans., Liberty Fund, 2004).

2 Anja Klug \& Tim Howe, The Concept of State Jurisdiction and the Applicability of the Non-Refoulement Principle to Extraterritorial Interception Measure, in EXtraterritorial IMmigration CONTROl: Legal Challenges, 69, 69-70 (Bernard Ryan \& Valsamis Mitsilegas, eds., 2010).

${ }^{3}$ See id.
} 
The primary international legal issue involved with interdiction at sea is whether it violates the principle of non-refoulement, or not returning a refugee back to a place where his or her life would be endangered. Nonrefoulement lies at the core of the 1951 Convention relating to the Status of Refugees and its 1967 Protocol, to which the U.S., Australia, and nearly all European states are parties. ${ }^{4}$ The principle is considered by most commentators to have acquired the status of a jus cogens norm. ${ }^{5}$ The Convention exempts states from the obligation of non-refoulement only when individual refugees present national security threats, or when an asylum-seeker has been involved in war crimes or criminal acts. ${ }^{6}$ International refugee law thus conflicts with the right of a sovereign state to expel aliens, and demands that states give certain protections to noncitizens.

Faced with tremendous numbers of people wishing to enter, wealthier states have increasingly restricted their borders to protect national security. The challenge of balancing domestic security interests with international human rights commitments has fallen to courts. Cases involving interdiction at sea and non-refoulement have reached the highest courts of the U.S., Australia, and the European Court of Human Rights (ECtHR). ${ }^{8}$ Each court has interpreted international refugee law differently in its jurisprudence, creating a discrepancy as to what non-refoulement actually requires. The U.S. and Australian courts have determined that their practices of interdiction at sea did not violate non-refoulement or their own domestic laws involving refugee protection. Most recently, the ECtHR determined that the European Union's practices of interdiction at sea did violate the principle of non-refoulement, forcing the EU to change its policies. International refugee law, and these courts' interpretations of it, continuously plays a major role in shaping the refugee and asylum law of nation-states. As states continue to develop creative solutions to manage migration, domestic courts will play an increasing role in interpreting international refugee law.

This article will analyze how the concept of non-refoulement has been treated in domestic courts. Drawing on cases from the U.S., Australia,

\footnotetext{
${ }^{4}$ Convention Relating to the Status of Refugees, art. 33, July 28, 1951, 189 U.N.T.S. 137 (hereinafter, "Convention"); 1967 Protocol Relating to the Status of Refugees, Jan. 31, 1967, 606 U.N.T.S. 267 (hereinafter, "1967 Protocol"). The U.S. is a party to the 1967 Protocol, which incorporates the Convention.

${ }^{5}$ See Jean Allain, The Jus Cogens Nature of Non-Refoulement, 13 INT'L J. REFUGEE L. 533 (2001).

${ }^{6}$ Convention at arts. $1(\mathrm{~F})(\mathrm{a})-(\mathrm{b})$.

${ }^{8}$ Sale v. Haitian Centers Council, 509 U.S. 155 (1993) (hereinafter, "HCC"); Ruddock v Vadarlis (2001) FCA 1329 (Austl.); Hirsi Jamaa and Others v. Italy, 27765/09, 2012 Eur. Ct. H.R.; M.S.S. v. Belgium and Greece, 30696/09, 2011 Eur. Ct. H.R.
} 
and the ECtHR, this article will compare how the Convention has been interpreted across countries and over time. Its object is to compare how the Convention and its core principle of non-refoulement have been creatively avoided and interpreted by courts. Comparing state jurisprudence on this topic helps determine what international refugee law actually requires of states. ${ }^{9}$ More broadly, this analysis sheds light on the question of what extraterritorial obligations human rights law requires.

This article fits squarely within the internal perspective on comparative international law. ${ }^{10}$ It employs the techniques of comparative law to illuminate our understanding of what international refugee law, although ostensibly uniform, means when applied in various jurisdictions. These country cases were selected because they are common asylum destinations for migrants traveling by sea. ${ }^{11}$ Moreover, their state practice has been influential in the development of international law, particularly refugee law, and the cases' fact patterns present similar circumstances that enable useful cross-jurisdictional comparison.

This article will proceed in three parts. Part I will discuss the tensions between the principle of non-refoulement and practices of interdiction at sea. Part II will review major cases that have reached high courts in the U.S., Australia, and Europe in recent years. Part III will analyze the problems that differing interpretations of non-refoulement creates within the international human rights regime, and conclude with the implications of these cases for understanding the extraterritorial reach of human rights law.

\section{THE OBLIGATION OF NON-REFOULEMENT IN INTERNATIONAL LAW}

The Convention's obligation of non-refoulement binds its 146 signatory states not to return to his country of origin anyone who meets the Convention definition of refugee, or any asylum-seeker awaiting refugee status determination. Non-refoulement does not require states to allow asylum-seekers to enter; it only requires that refugees not be returned to a place where they would be endangered. Most state practice has supported the idea that non-refoulement means non-return and non-rejection at the

\footnotetext{
${ }^{9}$ While executive or legislative interpretations of Convention, or national legislation implementing it, may also exist, discussion of these important units of analysis for Comparative International Law lies beyond the scope of this chapter.

${ }^{10}$ See Paul Stephan et al., Introduction, in PAUl StePhan, ET AL., EDS., COMPARATIVE INTERNATIONAL LAW (2015).

${ }^{11}$ See Katerina Linos, Lessons for Comparative Law from Comparative Politics, in Id.
} 
border. ${ }^{13}$ However, where exactly those borders begin is unclear when migrants are interdicted at sea.

In the modern environment of mass migration, compliance with the Refugee Convention creates a tremendous burden for states. The requirement of protection while claims are being processed has overwhelmed legal infrastructures, even in the most developed nations. The U.S., Europe, and Australia, for example, have built massive systems of detention centers to house migrants arriving at their borders. States have also adopted creative measures to comply with the letter of nonrefoulement. For example, to restrict migration, Western states have employed restrictive visa requirements, carrier sanctions, safe third country designations, readmission agreements, safe zones inside conflict areas, and programs of interdiction at sea. ${ }^{14}$ These policies have been criticized by UNHCR, the Office of the United Nations High Commissioner on Refugees, for amounting to human rights violations or non-refoulement.

To analyze states' obligations under non-refoulement, courts must confront the contested issue of when a state's human rights obligations under international law apply extraterritorially. States engaged in interdiction at sea first encounter refugees in offshore locations. The question arises as to whether states are bound by non-refoulement when they are technically operating outside their own territory. Cases involving refugee rights, then, have important implications for states' extraterritorial obligations under other human rights instruments.

\section{CASES InVOLVING Non-RefOULEMENT}

\section{A. U.S.: Sale v. Haitian Centers Council}

The 1993 case of Sale v. Haitian Centers Council is the only case that has brought the principle of non-refoulement before the U.S. Supreme Court. ${ }^{16}$ In the 1980s and 1990s, pro-democracy Haitians involved with the

${ }^{13}$ GUY GoOdwin-Gill \& JANE McAdam, The RefugEe In International LaW 208 (3rd ed., 2007).

${ }^{14}$ Deborah Anker, Joan Fitzpatrick \& Andrew Shacknove, Crisis and Cure: A Reply to Hathaway/Neve and Schuck, 11 HARV. HuM. RTS. J. 295, 297 (1998).

${ }^{16}$ HCC, 509 U.S. at 155. 


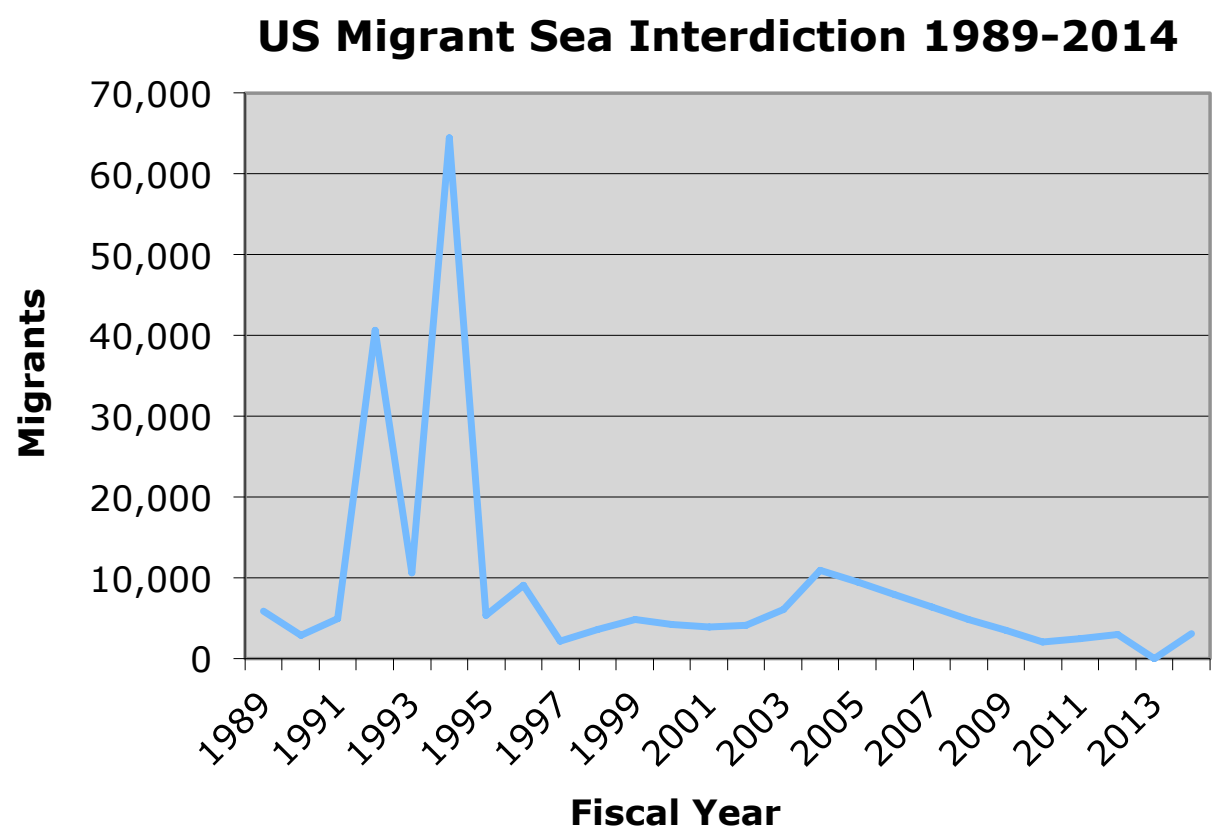

Convention for Democratic Unity movement (KID) worked to put JeanBertrand Aristide in power by advocating for democratic elections in Haiti. In September, 1981, the U.S. and Haitian governments signed a bilateral agreement creating a cooperative interdiction program. ${ }^{17}$ The U.S. Coast Guard began interdicting Haitian vessels and interviewing the migrants aboard to determine whether they had credible fears of political persecution, and were therefore eligible for refugee status. The Coast Guard brought to the U.S. those who were "screened-in" and returned all others to Haiti.

In 1990, following UN-supervised elections, Aristide was elected president. But democracy was short-lived. Aristide was ousted in a brutal coup on September 29-30, 1991. In its immediate aftermath, hundreds of KID supporters were killed, kidnapped, jailed, tortured, illegally detained, attacked with machetes, beaten, or had their property destroyed. ${ }^{18}$ Thousands of democracy supporters fled and sought refuge in Cuba or the United States. Their flight was further fueled by a severe economic downturn after the Organization of American States instituted a trade embargo against Haiti to protest the coup. ${ }^{19}$

During the six months following October 1991, the U.S. Coast

${ }^{17}$ Haiti-United States: Agreement to Stop Clandestine Migration of Residents of Haiti to the United States, 20 I.L.M. 1198 (Sept. 23, 1981); implemented by Exec. Order No. 12,324, 46 Fed, Reg. 48,109 (Sept. 29, 1981).

${ }^{18}$ BRANDT Goldstein, StORMING THE COURT 12 (2005).

${ }^{19}$ See id. 
Guard interdicted 34,000 Haitians. ${ }^{20}$ Initially, the Coast Guard conducted informal exclusion hearings for the Haitians aboard U.S. cutters, pursuant to the 1981 agreement. $^{21}$ But the sheer number of fleeing Haitians soon made screenings at sea impossible. After failed attempts to send Haitians to other Caribbean countries, the U.S. set up a makeshift camp at Guantanamo Bay to house Haitians while it conducted exclusion hearings. ${ }^{22}$ However, the facilities at Guantanamo could only accommodate 12,500 persons, and soon became overcrowded. On May 22, 1992, President Bush issued Executive Order 12807, authorizing the Coast Guard to summarily repatriate Haitians without screening.

A group of these Haitians, represented by a team from Yale Law School led by Professor Harold Koh, sued the U.S. Government, claiming it had violated its own domestic immigration laws and the Convention by forcibly refouling them without individualized processing. ${ }^{23}$ At the heart of the litigation was $\S 243(\mathrm{~h})$ of the Immigration and Nationality Act, which states:

[t]he Attorney General shall not deport or return any alien . . . to a country if the Attorney General determines that such alien's life or freedom would be threatened in such country on account of race, religion, nationality, membership in a particular social group, or political opinion. $^{24}$

This provision was intentionally drafted to mirror the non-refoulement obligations in the Convention.

The Haitians prevailed in the Second Circuit, and the Government appealed the case to the Supreme Court. Meanwhile, the Haitian crisis became a major issue in the presidential campaign between Bill Clinton and George Bush. While a candidate, Clinton criticized the interdiction program and vowed to overturn it. Once elected, upon news that Haitians were building boats in preparation for his inauguration, Clinton reversed course and endorsed the interdiction program. ${ }^{25}$

${ }^{20} \mathrm{HCC}, 509$ U.S. at 163.

${ }^{21}$ See id.

${ }^{22} I d$. at 163.

${ }^{23}$ See Harold H. Koh \& Michael J. Wishnie, The Story of Sale v. Haitian Centers Council: Guantanamo and Refoulement, in HumAn RigHTS ADVOCACY STORIES, (Deena Hurwitz, Margaret Satterthwaite, \& Douglas Ford eds., 2009).

${ }^{24} 8$ U.S.C. $\$ 1253(\mathrm{~h})(1)$ (1988 Supp. IV).

25 See David Martin, YLS Sale Symposium: Interdiction of Asylum Seekers-The Realms of Policy and Law in Refugee Protection, OPINIO JURIS (Mar. 15, 2014), http://opiniojuris.org/2014/03/15/yls-sale-symposium-interdiction-asylum-seekers-realmspolicy-law-refugee-protection/; reversal discussed in Koh \& Wishnie, supra note 23, at 


\section{The Decision}

In an 8-1 opinion, the Supreme Court held that neither $\S 243(\mathrm{~h})$ of the INA nor Article 33 of the Convention barred the U.S.'s program of interdiction at sea. Writing for the Court, Justice Stevens first determined that $\S 243(\mathrm{~h})$ limits the actions of the Attorney General only, and does not apply to the President or the Coast Guard. ${ }^{26}$ Second, the Court held that the INA applies "only to aliens who reside in or have arrived at the border of the U.S.," and not extraterritorially. ${ }^{28}$ The Court cited the presumption against extraterritoriality in American law and the fact that the INA itself makes no reference to extraterritorial application. ${ }^{29}$ The Court explained that Congress' choice to use both the words "return" and "deport" together in the 1980 Amendment demonstrates that the statute is not meant to apply extraterritorially, since the use of two words refers to both deportation and exclusion proceedings. ${ }^{30}$

Turning to the Convention, the Court held that the U.S. did not incur an extraterritorial obligation by acceding to the 1967 Protocol. The Court found that neither Congress nor the Executive Branch explicitly mentioned assuming any extraterritorial obligations when the U.S. acceded to the Protocol, and therefore, the U.S. could not have intended to do so. ${ }^{32}$ First, the Court noted that Article 33.2 of the Convention contains an "explicit reference . . . to the country in which the alien is located." " prohibition against refoulement applied on the high seas, "no nation could invoke the second paragraph's exception with respect to an alien there." 34 In the Court's view, extraterritorial application of Article 33.1 would "create an absurd abnormality: dangerous aliens on the high seas would be entitled

398.

${ }^{26}$ HCC, 509 U.S. 155, 171-74 (1993).

${ }^{28} \mathrm{Id}$. at 160 .

${ }^{29}$ See id. at 173 .

${ }^{30}$ See id. at $174-75$.

${ }^{32}$ Haitian Centers Council, 509 U.S. at 178.

${ }^{33}$ Id. at 179 . Article 33, section 1 of the Refugee Convention reads: "No Contracting State shall expel or return ('refouler') a refugee in any manner whatsoever to the frontiers of territories where his life or freedom would be threatened on account of his race, religion, nationality, membership of a particular social group or political opinion." Article 33, section 2 of the Refugee Convention reads, "The benefit of the present provision may not, however, be claimed by a refugee whom there are reasonable grounds for regarding as a danger to the security of the country in which he is, or who, having been convicted by a final judgment of a particularly serious crime, constitutes a danger to the community of that country."

${ }^{34}$ HCC, 509 U.S. at 179-180. 
to the benefits of [the prohibition against refoulement in Article 33.1] while those residing in the country that sought to expel them would not." 35 The Court thus read a geographic limitation into the prohibition against refoulement in Article 33.1 based on the language in Article 33.2. They decided that if the exception to the rule of non-refoulement is geographically limited to the territory of the country that the refugees are in, the rule must have that limitation as well.

The Court also reasoned that Article 33.1 uses both "expel" and "return ('refouler')," and that "refouler" has a legal meaning narrower than its common meaning. "Refouler" better translates to "repulse," "repel," "drive back," or "expel," implying that "return," as used in the Convention, "means a defensive act of resistance or exclusion at a border rather than an act of transporting someone to a particular destination." 37 Thus, it concludes that the Protocol was not intended to apply extraterritorially. After interpreting the text of the INA and the Convention, the Court further supported its argument by looking to the Convention's travaux préparatoires. Three non-U.S. drafters had stated that they did not intend Article 33 to apply extraterritorially. ${ }^{38}$ While nothing suggests that other signatories agreed with these delegates, the Court adopted their position. ${ }^{39}$

\section{Justice Blackmun's Lone Dissent}

Justice Blackmun issued a blistering dissent rejecting the majority's interpretation of both $\S 243(\mathrm{~h})$ of the INA and especially the Convention's prohibition against refoulement. Blackmun noted that the Refugee Act of 1980 indisputably was amended to align U.S. immigration law with the Convention. $^{40}$ The plain language of Article 33.1 does not include any geographical limitations. In Blackmun's view, “The terms are unambiguous. Vulnerable refugees shall not be returned. The language is clear, and the command is straightforward; that should be the end of the inquiry." 41 Until this litigation, he says, "the Government consistently acknowledged that the Convention applied on the high seas."42 The prohibition against refoulement, however translated, clearly "prohibits the Government's actions." 43 He notes that the statements of the Convention's

\footnotetext{
${ }^{35} \mathrm{Id}$. at $179-180$.

${ }^{36}$ See id. at 180 .

${ }^{37} \mathrm{Id}$. at 182.

${ }^{38}$ See id. at $183-87$.

${ }^{39}$ See id. at 187.

${ }^{40}$ See id. at 190.

${ }^{41} \mathrm{Id}$. at 190.

${ }^{42} I d$.

${ }^{43} I d$. at 192-93.
} 
drafters are "not entitled to deference, were never voted on or adopted, probably represent a minority view, and ... do not address the issue in this case. $" 44$

Similarly, Justice Blackmun found $\$ 243(\mathrm{~h})$ of the INA to be unambiguous. ${ }^{45}$ He finds that the Coast Guard is obviously an agent of the Attorney General, who is bound not to return refugees. ${ }^{46}$ Moreover, by deleting the words "within the United States" from the pre-1980 version of $\S 243(\mathrm{~h})$, Congress clearly meant for it to apply extraterritorially. ${ }^{47} \mathrm{He}$ states that rather than the presumption against extraterritoriality, the Court should have relied on the Charming Betsy canon, the idea that a Congressional act should never be construed to violate the law of nations if any alternative construction is possible. ${ }^{48}$ Invoking the Convention's enactment in response to the refoulement of Jewish refugees during World War II, Blackmun ends on a cautionary note:

The refugees attempting to escape from Haiti do not claim a right of admission to this country. They do not even argue that the Government has no right to intercept their boats. They demand only that the United States, land of refugees and guardian of freedom, cease forcibly driving them back to detention, abuse, and death. That is a modest plea, vindicated by the treaty and the statute. We should not close our ears to it.

These words would inspire European justices to adopt his conclusion.

\section{Impact}

The Sale decision permits U.S. presidents to utilize interdiction at sea whenever it is convenient for restricting migration. In December 1993, Clinton agreed to change the direct return policy after intensive lobbying by human rights organizations. The Inter-American Commission of Human Rights and UNHCR condemned the U.S. interdiction program. ${ }^{49}$ Despite this, after Aristide's second removal from power, George W. Bush reinstated the program.

The U.S. interdiction at sea program is said to have inspired similar

${ }^{44} I d$. at 198.

${ }^{45}$ See id. at 199.

${ }^{46}$ See id, at 200-01.

${ }^{47} I d$. at 202.

${ }^{48}$ See id. at 207.

${ }^{49}$ See Inter-American Commission on Human Rights Report No 51/96, \ 171, (March 13, 1997); Brief for UNHCR as Amici Curiae Supporting Respondents, Sale v. Haitian Centers Council, 509 U.S. 155 (1993). 
policies in Australia and Europe. However, Australian and European courts have interpreted non-refoulement to expand it beyond what the U.S. Supreme Court requires. The ECtHR explicitly criticized the Sale decision in its own opinion on non-refoulement.

\section{B. Australia: The Tampa Case}

Australian courts have sought to avoid reaching Australia's commitments under the Convention. Their controversial human rights decisions take place against the backdrop of heated political debate. Australian policy toward "boat people" has been a major issue in national politics in recent decades. The proximity of its outlying islands to Southeast Asia makes it a convenient destination for migrants and human smugglers. A favorite landing spot is Christmas Island, an Australian external territory that lies only 360 kilometers south of Java and 2600 kilometers Northwest of Perth.

In 2001, a very controversial case reached the Federal Court of Australia, the highest court of appeals before the High Court. On August 26, 2001, the MV Tampa, a Norwegian commercial ship, rescued 433 people from a sinking craft in international waters near Christmas Island. The passengers on the shoddy, overcrowded boat were mostly Afghans and Iraqi asylum-seekers who had been smuggled to Australia via Indonesia. The Tampa's captain determined that some of the migrants needed urgent medical attention and sought help from Australian authorities.

When no assistance arrived, the Tampa initially headed toward Indonesia, but turned for Christmas Island when five passengers threatened to commit suicide. 136 boats sailing from Indonesia had been allowed to enter Australia in the preceding 12 months, but the government refused to allow the Tampa to land. ${ }^{51}$ Commentators have speculated that the Liberal government was reluctant to allow additional asylum-seekers to enter in a highly visible way so close to an election. ${ }^{52}$ As one cartoonist noted, the 433 people on the Tampa represented millions of votes. ${ }^{53}$ In the ensuing litigation, the government did not explain why it singled out the Tampa, but

51 Susan Kneebone, Controlling Migration by Sea: The Australian Case, in 21 EXTRATERRITORIAL IMMIGRATION CONTROL 357 (Bernard Ryan \& Valsamis Mitsilegas eds., 2010).

${ }^{52}$ See id.

${ }^{53}$ See id. 


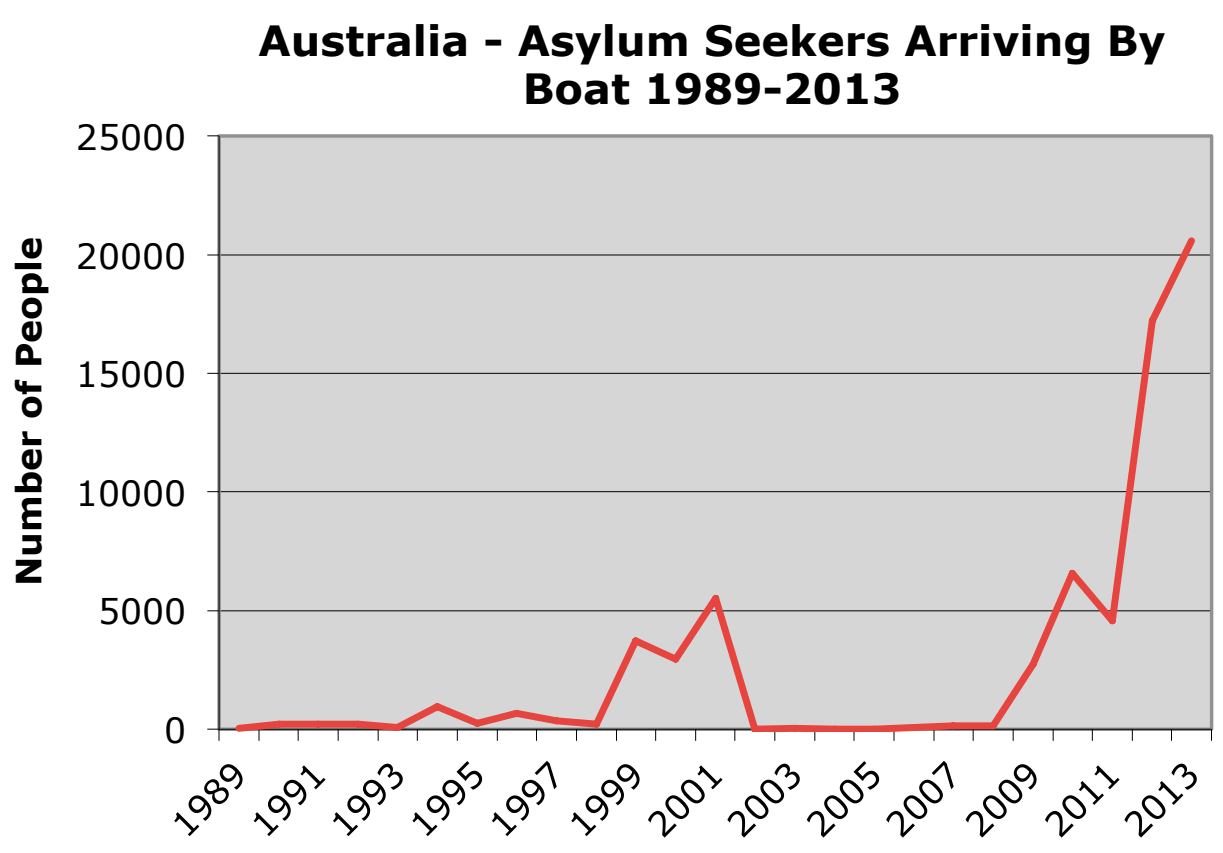

admitted that it did not want the passengers to enter Australia's migration zone, where they could claim protection under the Convention. ${ }^{54}$

The Australian Secretary of the Department of Immigration and Multicultural Affairs determined that the passengers were the responsibility of Indonesia and Norway, and so refused to allow the ship to land. Instead, 45 Australian Special Armed Services troops stormed the ship as the public watched. The passengers expressed to the Australian government their desire to seek peaceful asylum. The SAS forces responded by controlling the Tampa for more than a week, refusing to allow it on Australian soil, and even closing the harbor and cutting off communication with the passengers. By this time, the case had attracted international attention. UNHCR called the governments of Australia, Norway, and Indonesia to Geneva to try to broker a solution.

When talks broke down, Australia arranged for the rescuees to be transferred to Nauru. No one explained this plan to the passengers in their native language, and no processing system was established in Nauru. On September 3, the passengers were transferred to an Australian ship. At this point, an Australian NGO filed a lawsuit on behalf of the passengers in Australian Federal Court, arguing that they had been unlawfully detained aboard the Tampa and petitioning for their right to enter Australia.

${ }^{54}$ See id. 


\section{The Decision}

In what became known as the "Tampa Case," the Federal Court avoided the issue of non-refoulement. The court held that the Government must release the rescuees onto mainland Australia if they refused to go to Nauru or New Zealand, which had by then agreed to take some of the passengers. The court held that the removal of aliens is governed entirely by statute, namely the Migration Act of 1958, leaving no room for the exercise of prerogative power to remove particular aliens. Although it could easily have done so, the court did not address the issue of refoulement, the asylum claims of the rescuees, or the potential refugee claims among them. The Convention was not mentioned, and the plaintiffs were referred to as "rescuees" throughout the decision, a peculiar term that suggests the court wished to avoid the terms "asylum-seeker" or "refugee."

The decision was quickly appealed to the full Federal Court and became titled Ruddock v. Vadarlis. ${ }^{55}$ In the meantime, hours after the Federal Court's initial decision, two airplanes struck the twin towers of the World Trade Center in New York, forever changing both public opinion and immigration policies on the entry of Afghans and Iraqis. With an election looming, the Liberal Government needed to curry votes by appearing tough on refugees. ${ }^{56}$

On September 18, 2001, the full Federal Court overturned itself. It held that the Australian Minister of Immigration Affairs acted within his executive power under Section 61 of the Australian Constitution by preventing the rescuees from landing on the mainland. The Migration Act of 1958 did not abrogate this power. In the court's view, Australian authorities did not restrict the rescuees' freedom, since they were free to go to a third country. Therefore, the refugees were not detained by Australia, but actually had been detained by the captain of the Tampa. The odd term "rescuee" was again used throughout the decision. The rescuees' asylum claims and the question of whether Australia had violated its obligations under the Convention were never mentioned. Petitioners' appeal to the High Court of Australia was subsequently denied. Implicitly criticizing the decision, UNHCR awarded the Tampa's captain its Nansen Refugee Award for outstanding work on behalf of the forcibly displaced.

2. Impact

After "The Tampa Affair," the Howard Government responded by

${ }_{56}^{55}$ Ruddock v. Vadarlis (2001) FCA 1329 (Austl.)

${ }^{56}$ Penelope Mathew, Australian Refugee Protection in the Wake of the Tampa, 96 AM. J. INT'L L. 661, 662 (2002). 
developing the ominously named "Pacific Solution." Commentators have speculated that the U.S.-Caribbean interdiction program and the Sale decision inspired this plan for interdiction of migrants at sea. ${ }^{57}$ Seven new parliamentary acts restricted the entry of aliens into Australia and validated all actions taken in the wake of the Tampa Affair. ${ }^{59}$ They developed a new category of territory, the "excise offshore place," which included territories outside the mainland like Christmas Island. An unlawful alien entering via an excise offshore place would now be identified as an "offshore entry person" and prohibited from submitting a valid visa application unless the Minister of Immigration deems it in the public interest for them to do so. Authorized by the legislature, the Australian Defense Forces introduced Operation Reflex to interdict boats carrying potential asylum-seekers before they reached Australian territory. The acts also allowed Australia to identify other countries where they could redirect offshore entry persons. Sending asylum-seekers to a safe, third country does not violate the principle of nonrefoulement if the third country is safe for migrants and no danger of refoulement exists there. Australia has identified Nauru and Papua New Guinea, and recently Cambodia, as places to send asylum-seekers, despite protests from human rights groups that conditions there are unsatisfactory. Once in these third countries, Australia's Migration Act no longer applies, so aliens could submit a valid visa application. However, these aliens would be limited to certain visa categories and unable to apply for a protection visa. In other words, asylum-seekers directed to third countries would never receive refugee status in Australia.

After the 2008 election, Prime Minister Kevin Rudd's Labor government suspended the Pacific Solution, although migration had dropped dramatically during the years it had been in effect, per the figure above. ${ }^{60}$ While the policy was suspended, the High Court of Australia clarified the rights of asylum-seekers under the Pacific Solution. In the M61 Case, the Court held that asylum-seekers detained in excised offshore places are individuals to whom Australia owes protection, and therefore are entitled to procedural fairness and access to courts. ${ }^{61}$ In M70, the High

${ }^{57}$ See id. at 666.

59 Border Protection (Validation and Enforcement Powers) Act 2001 (Cth) (Austl.); Migration Amendment (Excision from Migration Zone) Act 2001 (Cth); Migration Amendment (Excision from Migration Zone) (Consequential Provisions) Act 2001 (Cth); Migration Legislation Amendment Act (No. 1) 2001 (Cth); Migration Legislation Amendment Act (No. 5) 2001 (Cth); Migration Legislation Amendment Act (No. 6) 2001 (Cth).

${ }^{60}$ See Ariane Rummery, Australia's "Pacific Solution" draws to a close, UNHCR, (Feb. 11, 2008) http://www.unhcr.org/cgibin $/$ texis $/$ vtx/search?page $=$ search $\&$ docid $=47 \mathrm{~b} 04 \mathrm{~d} 074 \&$ query $=$ australia

${ }^{61}$ Plaintiff M61/2010E v Commonwealth of Australia \& ORS; Plaintiff M69 of $2010 \mathrm{v}$ 
Court held that two offshore entry persons who claimed to be refugees under the Convention could not be released to Malaysia without processing of their refugee claims in Australia. ${ }^{62}$ The Court reasoned that the Minister of Immigration did not have the power to enter into an agreement with Malaysia to release asylum-seekers there, since Australia could not ensure that Malaysia would give adequate and fair protection to asylum-seekers. Therefore, sending asylum-seekers to Malaysia would potentially violate Australia's non-refoulement obligations.

In the wake of an influx of boat people and a number of publicized deaths at sea, the succeeding Labor government reinvigorated the Pacific Solution, reopening the Nauru and Manus Island detention centers for offshore processing of asylum-seekers, striking a new agreement with Papua New Guinea for third-country processing and giving unauthorized maritime arrivals no possibility of obtaining Australian residency. Prime Minister Tony Abbott defeated Kevin Rudd in 2014 on a campaign promise to "stop the boats."

So far, the High Court has largely upheld Abbott's policies regarding asylum-seekers, although they have come under fire domestically and internationally. In January 2015, the High Court upheld Australia's interdiction of 157 Sri Lankan asylum-seekers and subsequent transfer to Nauru. ${ }^{64}$ The court held that interdiction at sea and third country-processing were legal under the Maritime Powers Act, but that Australia was bound to ensure the asylum-seekers' safety in any country to which they were transferred. The court declined to reach the question of Australia's nonrefoulement obligations, but several justices raised concerns about the practice of summary return. The court also left open the question of whether the Australian government has the power to turn back the boats. UNHCR promptly criticized the decision. ${ }^{65}$ Another case set to come before the Court seeks to have the Australian government's agreement for thirdcountry processing in Papua New Guinea declared unconstitutional. If successful, this case has the potential to invalidate Australia's entire offshore processing program. ${ }^{66}$

Thus, in the wake of Ruddock v. Vadarlis, Australia has continued to

Commonwealth of Australia \& ORS (2010) HCA 41 (Austl.).

${ }^{62}$ Plaintiff M70/2011 v Minister for Immigration and Citizenship (2011) HCA 32 (Austl.).

${ }^{64}$ CPCF v. Minister for Immigration and Border Protection \& ANOR (2015) HCA 1 (Austl.).

65 UNHCR, UNHCR Legal Position, February 4, 2015, http://www.unhcr.org/54d1e4ac9.html.

${ }^{66}$ Madeleine Morris, Asylum seekers launch High Court challenge to legality of offshore detention system, May 14, 2015, http://www.abc.net.au/news/2015-05-14/asylumseekers-launch-high-court-challenge/6471376. 
experiment with migration-control policies involving interdiction at sea and extraterritorial processing by third countries. Its High Court has repeatedly held that Australia's non-refoulement obligations extend to ensuring that third countries will not subject asylum-seekers to ill-treatment and will not refoule them. However, Ruddock still stands, and neither the Australian Federal nor High Court has addressed whether Australia's interdiction at sea practices conflict with its non-refoulement obligations, despite repeated opportunities to do so.

\section{ECHR: Hirsi Jamaa and M.S.S v. Belgium and Greece}

Faced with a recent influx of asylum-seekers crossing the Mediterranean, Europe has sought to restrict its borders. In 2003, the European Union enacted the Dublin Agreement, designed to discourage migration by sending asylum-seekers back to their country of entry within Europe for processing. ${ }^{69}$ In 2004, the European Union also created an extensive border patrol agency called Frontex. ${ }^{70}$ NGOs have repeatedly accused Frontex of non-refoulement for its interdiction and return of migrants at sea. ${ }^{71}$ Southern European states, particularly Italy and Greece, are the most frequent points of entry for migrants. Both have built massive detention centers to house asylum-seekers while they await processing. UNHCR and NGOs have criticized Greece, in particular, for lengthy processing times and unsafe conditions for asylum-seekers. Cases against Italy and Greece involving improper treatment of asylum-seekers have come before the ECtHR.

The ECtHR interprets non-refoulement more liberally than courts in the U.S. and Australia. Since the European Union itself is not a signatory to the Convention, the ECtHR cannot consider violations of non-refoulement. However, Article 3 of the European Charter of Human Rights (ECHR) prohibits the related practices of torture and inhuman or degrading treatment or punishment. In 2011, the ECtHR issued a decision similar to that of the Australian High Court in M70 in M.S.S. v. Belgium and Greece. ${ }^{73}$ Belgium had sent an asylum-seeker back to Greece, his point of first entry to Europe, without ensuring that Greece would adequately protect him, process his claims, and not put him at risk for refoulement. The

\footnotetext{
${ }^{69}$ See Council Regulation 343/2003, 2003 O.J. (L/50/1), sometimes known as "Dublin II."

${ }^{70}$ Council Regulation (EC) 2007/2004, 2004 O.J. (L 349/1) authorized Frontex, which became operational on October 3, 2005.

${ }^{71}$ See, e.g., $41^{\text {st }}$ Meeting of the UNHCR ExCom Standing Committee, March 4-6, 2008, NGO Statement on International Protection: The High Commissioner's Dialogue on Protection Challenges.

${ }^{73}$ M.S.S. v. Belgium and Greece, 30696/09, 2011 Eur. Ct. H.R..
} 
ECtHR held that both Belgium and Greece were responsible for violations under Article 3 of the ECHR. In doing so, the ECtHR effectively held that Article 3 of the ECHR prohibits refoulement.

One year later, the case of Hirsi Jamaa and Others v. Italy became the first ECtHR case involving the interdiction of migrants at sea. ${ }^{74}$ In 2008 , Italy and Libya signed a Treaty of Friendship, Partnership and Cooperation that included provisions for mutual assistance in fighting irregular migration. ${ }^{75}$ Italy and Libya agreed to joint operations in the Mediterranean to interdict and return boats carrying illegal migrants. ${ }^{76}$ Data from Italian immigration officials shows that the number of irregular migrants arriving from North Africa decreased since this Treaty was adopted. ${ }^{77}$

Human rights organizations decried Italy's interdiction practices. ${ }^{78}$

NGOs argued that the policy subjected returned migrants to ill treatment in Libya, amounting to a violation of ECHR Article 3. ${ }^{79}$ Further, Italian authorities have openly acknowledged that they do not engage in formal identification and processing of migrants intercepted at sea. ${ }^{80}$ Italian officials conducted these practices even though Article 4 of the ECHR's Protocol No. 4 bans collective expulsion of aliens.

\section{The Decision}

In 2009, eleven Somali nationals and thirteen Eritrean nationals brought suit before the ECtHR alleging violation of these two articles of the ECHR. The migrants had been among two hundred individuals aboard three vessels crossing the Mediterranean Sea from Libya. ${ }^{81}$ On May 6, 2009, the

\footnotetext{
74 See Hirsi Jamaa and Others v. Italy, 27765/09, 2012 Eur. Ct. H.R. (hereinafter, "Jamaa")

${ }^{75}$ See id. at $\$ 19-20$.

${ }^{76}$ By July 30, 2009, Italy had pushed back 602 migrants to Libya and 23 to Algeria. European Committee for the Prevention of Torture and Inhuman or Degrading Treatment

or Punishment Report to the Italian Government on the July 27-31, 2009 Visit to Italy, CPT (Apr. 28, 2010) (hereinafter "CPT Report"].

77 See Violeta Moreno-Lax, Seeking Asylum in the Mediterranean: Against a Fragmentary Reading of EU Member States' Obligations Accruing at Sea, 23 INT'L J. REFUGEE L. 174, 184 (2011).

${ }^{78}$ See, e.g., UNHCR, Press Release: UNHCR Deeply Concerned Over Returns from Italy to Libya (May 7, 2009); Italy/Libya: Migrants Describe Forced Returns, Abuse: EU Should Press Italy to Halt Illegal Forced Returns to Libya, Human Rights WATCH (Sept. 21, 2009) http://www.hrw.org/news/2009/09/17/italylibya-migrants-describe-forcedreturns-abuse); CPT Report, supra note 76.

${ }^{79}$ See Moreno-Lax, supra note 77, at 207; see Convention for the Protection of Human Rights and Fundamental Freedoms, art. 3, Apr. 11, 1950, E.T.S 5 (hereinafter "ECHR").

${ }^{80}$ See CPT Report, supra note 76, at 13.

${ }^{81}$ See Jamaa, at $\$ 9$.
} 
Italian police and coast guard intercepted them in international waters approximately 35 nautical miles south of Lampedusa. The forces transferred them to military ships, where their personal effects and identity documents were confiscated. Ten hours later, the Italian forces turned the migrants over to the Libyan authorities in the Port of Tripoli. ${ }^{82}$ Aboard the ship, Italian officials did not attempt to identify, interview, or process the migrants; nor did they inform them of their destination before returning them to Libya. ${ }^{83}$

Two of the applicants later died "in unknown circumstances." Fourteen others were granted refugee status by UNHCR offices in Tripoli, and brought suit before the ECtHR. The applicants argued that Article 3 of the ECHR and Article 4 of Protocol No. 4 required Italy to allow them to make a claim for asylum and to review their claims on an individual basis, and prohibited Italy from returning them to a state where they might be subject to mistreatment. ${ }^{84}$ The applicants further argued that they were arbitrarily refouled, and had been denied the opportunity to challenge their refoulement or seek refugee protection under international law.

The applicants first had to prove that they had standing before the ECtHR because they were interdicted on the high seas. They brought suit under Article 34 of the ECHR, which permits "applications from any person, non-governmental organization or group of individuals claiming to be the victim of a violation by one of the High Contracting Parties." Italy argued that its actions were not subject to the ECHR because they occurred outside of Italian territory and because Italy did not exert absolute and excessive control over the applicants since they did not use force. ${ }^{85}$ Moreover, they did not involve a "maritime police action" because they were simply rendering the humanitarian aid required by the United Nations Convention on the Law of the Sea (UNCLOS) and the Convention on Maritime Search and Rescue. ${ }^{86}$

The Court held that the case fell within its jurisdiction and that the migrants had standing. Relying on a standard developed in other cases involving extraterritoriality, the Court held that Italy had exerted "effective control" over the migrants' craft, and over the migrants itself when they took them aboard the military vessel flying the Italian flag. ${ }^{87}$ The alleged violations took place entirely aboard the Italian ships. Thus, the fact that they were intercepted on the high seas did not remove them from

${ }^{82}$ See id. at $\S \S 10-12$.

${ }^{83}$ See id. at $\$ 11$.

${ }^{84}$ See id. at $\$ \S 84-88$.

${ }^{85}$ See id. at $\S 64$.

${ }^{86}$ United Nations Convention on the Law of the Sea, art. 98, Dec. 10, 1982, 1833

U.N.T.S. 3.

${ }^{87} \mathrm{Jamaa}$, at $\S 64$. 
jurisdiction. ${ }^{88}$ Regarding Italy's UNCLOS argument, the Court pointedly stated that Italy could not "circumvent its 'jurisdiction' under the Convention by describing the events at issue as rescue operations . . .."89

Moving to the merits, the Court found that Italy violated Article 3 and Article 13 of the ECHR and Article 4 of the Protocol. The Court found Italy violated Article 3 by returning the migrants to Libya, where they were at risk of inhuman and degrading treatment. Moreover, in Libya they would be exposed to the risk of repatriation to Somalia and Eritrea, where they would likely be subjected to maltreatment. ${ }^{90}$ The Court stressed that "expulsion, extradition or any other measure to remove an alien may give rise to an issue under Article 3, and hence engage the responsibility of the expelling state under the Convention." It affirmed the "absolute character" of the prohibition against torture and inhuman and degrading treatment under Article 3. The Court concluded that, given numerous reports by international organizations, states, and NGOs regarding the lack of safety in Libya, Italy "knew or should have known" that the migrants could be exposed to maltreatment, in violation of Article 3. The Court further held that Italy had violated Article 4 of Protocol No. 4 by not allowing the migrants to make asylum claims or receive individual consideration, which constituted an illegal collective expulsion of aliens. ${ }^{91}$ Finally, the court held that Italy violated Article 13 of the Convention, since the applicants did not have an effective remedy or procedural process that they could pursue after the incident occurred. The migrants were denied the protections of Article 13 because they were offered no processing aboard the Italian ships, and were not informed of their destination before they were returned to Libya.

The majority opinion hearkened back to Justice Blackmun's dissent in Sale v. Haitian Centers Council, stating:

The words of Justice Blackmun are so inspiring that they should not be forgotten. Refugees attempting to escape Africa do not claim a right of admission to Europe. They demand only that Europe, the cradle of human rights idealism and the birthplace of the rule of law, cease closing its doors to people in despair who have fled from arbitrariness and brutality. That is a very modest plea, vindicated by the European Convention on Human Rights. 'We should not close our ears to it.'

With that, the ECtHR issued a landmark decision in human rights law.

\footnotetext{
${ }^{88}$ See id. at $\$ \S 76-82$.

${ }^{89}$ See id. at $\$ 64$.

${ }^{90}$ See id. at $\S \S 138,158$.

${ }^{91}$ See id. at $\S 186$.
} 
The concurring opinion, issued by Justice Pinto de Albuquerque, directly discussed the principle of non-refoulement in relation to the ECHR. He argued that that neither migrants nor refugees should be subject to nonrefoulement. The justice stated that the prohibition against refoulement was "an absolute obligation of all states" and a jus cogens norm. Moreover, he argued "de jure refugees" deserved the same protection as "de facto refugees," since all share equivalent needs for international protection. Any difference of treatment between these two groups of refugees, or between refugees arriving individually or as part of a mass influx, would create a second class of refugees, subject to a discriminatory regime.

\section{Impact}

Hirsi Jamaa represents a landmark ruling in at least two respects. By holding that interdictions at sea fall within a state's jurisdiction, the Court effectively outlawed many contemporary European migrant interdiction practices. Interdiction at sea might still be possible in cases permitted by the law of the sea, but states may no longer refuse to process migrants, summarily repatriate them to a third country without ensuring their safety, or hide behind claims of impossibility due to mass influx. Also, migrants must now be able to challenge the decision to transfer them to another state. The second notable outcome of the Court's holding was its discrete pronouncement that Italy could not circumvent its ECHR obligations by arguing that it was only acting pursuant to obligations imposed on it by UNCLOS. Specifically, Italy is now foreclosed from using its bilateral migration agreement with Libya as a legal shield from its ECHR commitments. More broadly, this holding forecloses future reliance by European states on multilateral agreements or bilateral treaties to circumvent their obligations to incoming migrants. It also prohibits states from claiming they are engaging in humanitarian "rescue-at-sea" missions when in reality intercepting and turning back migrants. To comply with their obligations under the ECHR, member states must offer individual processing to migrants intercepted at sea.

Moreover, the decision implies that the obligation against nonrefoulement applies to migrants and not just to de jure refugees. ${ }^{92}$ The decision refers to "persons," "applicants," or "migrants"; nothing in it suggests that its prohibitions should not apply to all persons equally. The opinion implies that a state cannot apply lower standards to the treatment of

92 See Irini Papanicolopulu, Hirsi Jamaa v. Italy, Application No. 27765/09, in International Decisions, 107 AM. J. InT’L L. 396, 417, 421-22 (David P. Stewart, ed. 2013). 
economic migrants or any other category of migrant. ${ }^{93}$

In response to the decision, the European Parliament developed new legislation explicitly adding the protection against non-refoulement and the protection of fundamental rights to its rules governing maritime surveillance operations by Frontex. ${ }^{95}$ The new Regulation states that no one can be "disembarked in, forced to enter, conducted to or otherwise handed over to" an unsafe country where he or she would be at risk of the death penalty, torture, persecution, or other inhuman or degrading treatment, or where "the migrant's life or freedom would be threatened" on Refugee Convention grounds, as well as sexual orientation. ${ }^{96}$ The Regulation also banned "chain refoulement": a migrant cannot be handed over to a third country if that country itself would put the migrant at risk for refoulement. Reflecting the judgment in M.S.S. v. Belgium and Greece, the Regulation says that the Member State must consider the situation in the third country regarding safety for migrants and risk of chain refoulement before deciding whether to send a migrant there. The Regulation also grants the migrants certain procedural rights, stating that before any return to a third state the Member States must "use all means" to identify the migrants, assess their circumstances, inform them of their destination, and give them an opportunity to object and assert the non-refoulement rule.

It is unclear whether the ECtHR's rulings have been followed by all states, even before the Mediterranean migration crises of 2014 and 2015. ${ }^{97}$ Still, in principle, this landmark judgment could serve as guidance for other states to revise their enforcement of domestic migration laws to comply with international legal principles.

\section{CONCLUSION}

International refugee law is meant to be universally applicable, and its protection against refoulement absolute. However, the requirement of non-refoulement has been interpreted differently in different courts, making

\footnotetext{
${ }^{93}$ See id. at 422 .

${ }^{95}$ See Steve Peers, New EU rules on Maritime Surveillance: Will They Stop the Deaths and Push-Backs in the Mediterranean? STATEWATCH, (Feb., 2014) http://www.statewatch.org/analyses/no-237-maritime-surveillance.pdf.

${ }^{96}$ Commission Proposal for a Regulation of the European Parliament and of the Council Establishing Rules for the Surveillance of the External Sea Borders in the Context of Operational Cooperation Coordinated by the European Agency for the Management of Operational Cooperation at the External Borders of the Member States of the European Union, COD 2013/0106 (Feb. 12, 2014).

${ }^{97}$ See Italy: Summary Returns to Greece Violate Rights: Unaccompanied Children, Asylum Seekers Should Not Be Turned Away Human Rights WATch, (Jan. 22, 2013) http://www.hrw.org/news/2013/01/22/italy-summary-returns-greece-violate-rights.
} 
it unclear what the principle actually means. A human rights regime cannot be universal if it means different things in different places. When people migrate, they deserve the same human rights protections wherever they may go. But when law migrates, it may never be the same.

As the analysis above shows, courts in the U.S., Europe, and Australia do not agree what the obligation of non-refoulement means. The ECtHR and the Australian High Court say that non-refoulement requires the state of entry to ensure that moving an asylum-seeker to a third country will not put him in danger of persecution, maltreatment, or refoulement in that country. Nothing in U.S. law contradicts this principle, although the issue has not come before SCOTUS. However, SCOTUS (explicitly) and the Australian High and Federal Courts (implicitly) have allowed the summary return of refugees interdicted at sea. The ECtHR, meanwhile, has struck down the practice of summary returns.

What explains the divergence in these three opinions? The political context surrounding the decisions may provide some explanation for the courts' different interpretations of non-refoulement. In the U.S. and Australia, public opinion was either neutral or against the entry of large numbers of boat people. Europe, on the other hand, has come under criticism for its treatment of migrants. Recent upheavals in the Middle East have led to large influxes of migrants approaching Europe by sea. Many highly visible cases in which migrants have drowned crossing the Mediterranean have caused backlash in public opinion. In this context, the ECtHR decided Hirsi Jamaa, broadening the interpretation of nonrefoulement and requiring greater human rights protections for migrants.

The ECtHR's more expansive interpretation of non-refoulement can also be explained by its unique position as a tribunal. Unlike any courts in the U.S. and Australia, the ECtHR is a supranational court that is explicitly charged with enforcing and implementing a human rights convention. The ECtHR is therefore insulated from the political pressures in any single country. Its explicit mission to protect human rights would also weigh on the side of expanding human rights protections.

Analysis of these three cases provides guidance for nations seeking to apply migration controls that also comply with human rights norms. In the years since the SCOTUS decision in Sale v. Haitian Centers Council, the prohibition against refoulement has been increasingly recognized as an international legal obligation, as evidenced in the ECtHR cases and the Australian M70 case discussed above. Given the expanding definition of non-refoulement outside the U.S. and domestic and international criticism of Sale, another SCOTUS opinion explicitly permitting summary return of refugees seems unlikely. Still, Sale stands, the Australian and (pre-Hirsi Jamaa) European interdiction programs were modeled after the U.S. 
program it upheld. The Australian High Court will soon hear a direct challenge to its program of interdiction at sea that will have important repercussions for state practice elsewhere. If the High Court strikes down the program, the U.S. will become still more of an outlier in its human rights practices, and it and other countries employing summary returns will face increased pressure to stop.

Taken together, these decisions reveal the importance of international refugee law, especially the norm of non-refoulement, in affecting states' migration regulations. State practice of shifting migration control to the high seas or third countries to avoid triggering Convention protections shows that the norm of non-refoulement affects state action. Although the U.S. and Australian courts appear to narrow the concept of non-refoulement or ignore it, the actions of these states reveal how influential the concept has been. If states felt they could simply disregard international refugee law, they would not need to adopt expensive and complicated practices to avoid it. It is no surprise, then, that states fear that courts will take non-refoulement too far.

Future court cases will need to clarify the meaning of nonrefoulement. Overextension of non-refoulement may conflict with other national security and human rights concerns. Under the broadest interpretation of the prohibition against non-refoulement on the high seas, practically anyone on a boat interdicted at sea could claim asylum to receive at least temporary international protection. Anti-piracy programs have already been restrained because states fear that non-refoulement obligations will require them to protect pirates against return to their home countries. ${ }^{99}$ Given such quandaries involving the appropriate balance between nonrefoulement and national security, David Martin has argued that governments need discretion to adjust to rapidly changing circumstances and balance human rights protections with manageable migration policies. $^{100}$ Future decisions must clarify states' non-refoulement obligations and guide them in striking an appropriate balance.

Faced with increasing migration and asylum applications, states will likely continue to adopt creative policies to circumvent their nonrefoulement obligations. UNHCR has expressed that processing of asylumseekers within the territory of the intercepting state is strongly preferable to extraterritorial processing for human rights reasons. ${ }^{101}$ However,

99 See David Martin, Human Rights and Migration Management: Of Complexity, Balance, and Nuance, 106 AM. SOC'Y INT'L L. PROC. 69, 71 (2012).

${ }^{100}$ See id.

101 See UNHCR Division of International Protection, Protection Policy Paper: Maritime Interception Operations and the Processing of International Protection Claims: Legal Standards and Policy Considerations with Respect to Extraterritorial Processing, in 
extraterritorial screening or processing of asylum-seekers may be permissible, particularly when part of a burden-sharing arrangement to distribute the responsibilities of refugee protection. Third state processing, out of country processing, regional processing, and processing involving maritime vessels may all be permissible if they comply with the norm of non-refoulement and ensure that any third countries involved comply with generally accepted international human rights standards. The decisions in the ECtHR and Australian cases suggest that the "effective control" standard announced by the ECtHR may apply to migration control or other extraterritorial operations involving potential human rights violations. UNHCR views the "effective control" standard as now generally recognized as a norm in refugee law, and it is recognized as a standard in human rights cases more generally, with the U.S. being an outlier. ${ }^{102}$ Cases involving whether states comply with these human rights norms are likely to continue to come before high courts, including in the U.S., which can be said to have "effective control" over many areas in which its military operates, on the high seas and elsewhere. If these cases are used as precedent in cases involving U.S. military operations, the U.S. will be required to apply international human rights standards extraterritorially.

Beyond the non-refoulement context, cases involving interdiction at sea add to our understanding of jurisprudence on human rights overall. ${ }^{105}$ The question of the extraterritorial application of human rights treaties and domestic human rights guarantees has been an important and controversial issue in recent years. The EU has been called upon to provide human rights guarantees for both refugees and migrants who reach their borders by sea, and the Hirsi Jamaa decision suggests Europe should not distinguish between them. States increasingly conduct activities beyond their borders, from migration controls to targeted killings and activities involving military occupation or humanitarian intervention. The European and Australian judgments come at a time when domestic courts are looking to ensure accountability under domestic law for the extraterritorial actions of states, as evidenced in the recent Al-Skeini judgment in Europe ${ }^{106}$ and in

2 Rescue at Sea, Stowaways and Maritime Interception: Selected Reference MATERIALS, $97 \quad$ (Dec. 2011) http://www.unhcr.se/fileadmin/user_upload/PDFdocuments/Rescue_at_Sea_Stowaways_a nd_Maritime_Interception.pdf.

${ }^{102}$ See UNHCR Division of International Protection, supra note 101 at 115; Oona Hathaway et al., Human Rights Abroad: When Do Human Rights Obligations Apply Extraterritorially? 43 ARIZ. ST. L.J. 339 (2011).

${ }^{105}$ On the relationship between refugee law and human rights law generally, see Jill Goldenziel, Displaced: Why We Need New International Law to Protect Refugees, Displaced People, and Human Rights (forthcoming 2015).

106 See Al-Skeini v. United Kingdom, 55721/07 Grand Chamber, (July 7, 2011) 
constitutional judgments in the U.S. holding that international legal obligations and procedural rights guaranteed under the Constitution apply to the U.S.'s extraterritorial actions. ${ }^{107}$ The above cases suggest that international human rights guarantees extend beyond state borders to areas where states have effective control, and apply to non-citizens. The reach of these holdings, therefore, may soon migrate to other areas of human rights law.

(holding that the U.K.'s human rights obligations under ECHR applied extraterritorially to actions in Iraq).

107 See Boumediene v. Bush, 553 U.S. 723 (2008); Rasul v. Bush, 542 U.S. 466 (2004). 